\title{
GLYCOALKALOIDS OF Solanum transcaucasicum
}

S. M. Aslanov

UDC 547.944

The present paper gives the results of a study of the gly coalkaloids from the epigeal parts of Solanum transcaucasicum Pojark (family Solanaceae). From the plant material, which was collected in the Lenkoran' region of the Azerbaidzhan SSR in the period of budding, we have isolated $0.162 \%$ (on the dry weight) of combined gly coalkaloids.

The combined gly coalkaloids were separated by the method described previously [1]. This gave three individual substances: (I) with $\mathrm{mp} 276-279^{\circ} \mathrm{C},[\alpha]_{\mathrm{D}}{ }^{20}-57.5^{\circ}$ (c 0.62 ; pyridine), $\mathrm{R}_{f} 0.16$; (II) with $\mathrm{mp} 301-$

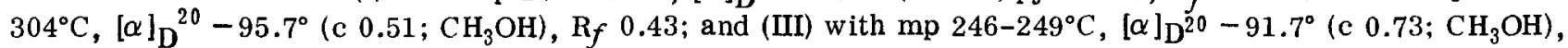
$\mathrm{R}_{f} 0.36$ [TLC in a fixed layer of KSK silica gel and gypsum $(8: 2)$ in the ethyl acetate-pyridine-water $(20$ : $5: 2)$ system with Dragendorff's reagent to reveal the spots].

The IR spectrum of (I) (UR-20 spectrophotometer) showed absorption bands in the following regions (cm-1): $3600-3200$ (OH and $\mathrm{NH}$ groups), 1640 (CO group), 1610 (double bond), 1450, 1410, $1370\left(\mathrm{CH}_{3}\right.$ and $\mathrm{CH}_{2}$ groups), $1140(>\mathrm{NH})$ [2], $1050\left(\mathrm{CH}_{2} \mathrm{OH}\right)$ [2], and 980; the IR spectrum of (II) had bands at 3550-3180 (OH and $\mathrm{NH}$ groups), 1640 (CO group), 1620 (double bond), $1460,1380\left(\mathrm{CH}_{3}\right.$ and $\mathrm{CH}_{2}$ groups), $1140(>\mathrm{NH}), 1060\left(\mathrm{CH}_{2} \mathrm{OH}\right)$ and 980; and the IR spectrum of (III) had bands at 3550-3180,1640,1610,1460, 1390, 1140, 1060, and 980.

On individual acid hydrolysis the substances gave the same aglycone, with $\mathrm{mp} 199-201^{\circ} \mathrm{C},[\alpha]_{\mathrm{D}^{0}}-91.7^{\circ}$ (c $0.73 ; \mathrm{CH}_{3} \mathrm{OH}$ ), $\mathrm{R}_{f} 0.73$, which was identified by a mixed melting point as solasodine $[3,4]$.

Paper chromatography of the hydrolyzates showed that substance (I) contained as the sugar residues D-glucose, D-galactose, and L-rhamnose, and substances (II) and (III) contained the same sugar residues, namely D-glucose and two molecules of L-rhamnose.

On the basis of their physicochemical constants, literature data [5-12], mixed melting points, and behavior on chromatograms, the substances were identified as solasonine (I), solamargine (II), and $\beta$-solamargine (III).

\section{LIT ERATURE CITED}

1. S. M. Aslanov, Khim. Prirodn. Soedin., 6, 776 (1970).

2. E. A. Tukalo and B. T. Ivanchenko, Khim. Prirodn. Soedin., 7, 207 (1971).

3. P. Boll and B. Anderson, Planta Med., 4, 10 (1962).

4. R. Kuhn, I. Low, and H. Trischmann, Chem. Ber., 88, 289 (1955).

5. M. Alkemeyer and H. Sander, Naturwiss., 46, 207 (1959).

6. R. Bognar and S. Makleit, Steroid-Alkaloid-Glykoside, 68,432 (1962).

7. R. Bognar and S. Makleit, Acta Chem. Univ. Debreceniensis, $\underline{8}, 61$ (1962).

8. P. Boll, Acta Chem. Scand., 12, 358 (1958).

9. K. Schreiber, Planta Medica, $\underline{6}, 435$ (1958).

10. K. Schreiber, Kulturpflanze, $\overline{1}, 422(1963)$.

11. S. Makleit and L. Dobas, Herba Hung., 2, 19 (1963).

12. S. Makleit and R. Bognar, Acta Chim. Acad. Sci. Hung., 38, 53 (1963).

V. L. Komarov Institute of Botany, Academy of Sciences of the Azerbaidzhan SSR. Translated from Khimiya Prirodnykh Soedinenii, No. 1, pp. 132-133, January-February, 1972. Original article submitted October 18, 1971.

- 1974 Consultants Bureau, a division of Plenum Publishing Corporation, 227 thest 17th Street, New York, N. Y. 10011. No part of this publication may be reproduced, stored in a retrieval system, or transmilted, in any form or by any means, electronic, mechanical, photocopying, microfilming, recording or otherwise, without written permission of the publisher. 1 copy of this article is available from the publisher for $\$ 15.00$. 